\title{
The National People's Congress Oversight Power and the Role of the CCP
}

\author{
ChaO CHIEN-MiN
}

\begin{abstract}
The urbanization and the structural and institutional changes that have taken place in China in the past two decades have resulted in the collapse of the old system and the germination of a tremendous number of irregularities. To redress the malfeasance brought about by the new decentralization of economic resources, the People's Congresses (PCs) are taking the lead in another round of incremental political reforms. The combination of specialization and centralization of leadership has led to an augmentation of legislative oversight. Measures developed by the legislative institutions, such as pingyi (evaluation) and zhifa jiancha (inspection of implementation of laws), have enlivened a lethargic local political scene and given rise to the committee autonomy. These political reforms have transformed local politics forever, forcing the central government to follow suit. The urgent need for institutional mechanisms to counter the vices associated with socialist market reform has prompted the Party to turn its attention to the People's Congresses. Consequently, a Leninist party-state system has been transformed into a new system in which the Party is allied simultaneously with the executive and the legislative branches. A preliminary and limited balance of power is now emerging in which the Party is not totally immune. The newly accrued legislative powers have not only redefined the tenets of Party leadership, but also rewritten its relations with the executive branch. Although the PCs are still often barred from vital decision-making, new devices such as pingyi and zhifa jiancha are forcing some local officials to have second thoughts before straying too far from legal boundaries.
\end{abstract}

\section{Introduction}

How to gain more autonomy by insulating itself from executive branch interference while at the same time representing the interests of the constituency-these have been the central issues of Western legislative governments, which have a strong tradition of checks and balances. However, these two goals are constantly at odds, as is demonstrated by the United States Congress. As Kenneth A. Shepsle (1988) observed, before the 1970s, House Standing Committee members focused on insulating the House from the executive branch, rather than on representing constituents' interests. Similar trade-offs have been noted in other 
legislatures, too. While writing about the German Bundestag, for instance, Schuttemeyer (1994: 51) suggests that policy-making by an increasingly professionalized parliament has been stressed at the cost of ties between representatives and constituents. Studies of newly emerging legislatures have manifested an analogous trend in that legislators are devoting more attention to law-making at the expense of their engagement with voters (Colton 1996).

Facing this dilemma, most scholars agree that institutionalization is a key indicator of legislative change, since institutionalization inevitably brings enhanced autonomy to a legislature (Canon 1989; Polsby 1968; Squire 1992). Whether a parliament can develop an identity of its own has long been a focus of legislative attention. Typically, scholars use measures such as membership turnover, competition, and difficulty of entry to leadership as a gauge of a legislature's autonomy and its success at 'boundary-maintenance'.

China's National People's Congress (NPC) is known for functioning as a rubber-stamp institution. This body has proved unable to create an autonomous niche for itself, in order that interventions from other power sources, such as the Communist Party, can be effectively reduced to the minimum. However, reforms have been undertaken since the 1980s to revitalize the institution's functions. Amid the raging wave of corruption and malfeasance caused by the decentralization of resources for the sake of developing the economy, the People's Congress is increasingly viewed as a formidable organ to combat the irregularities. How far has the NPC travelled down the road towards institutionalization? Can the NPC evolve into a representative body similar to its counterpart in the West? Has the relationship between the NPC and the CCP changed over the years as the economic reforms progress? This article will try to provide answers to these questions.

The article first examines the theory of legislative institutionalization as extrapolated from the US experience, and then goes on to examine China's National People's Congress. There can be no doubt that the autonomy of the National People's Congress has increased greatly since the 1980s. With regard to the issues of strengthening functions, institutionalizing organizational structures and supporting facilities of the NPC standing committees, here too one finds evidence of increased professionalization. The article concludes by reinforcing the observation that the legislature in China is more professionalized and therefore more autonomous. The traditional function of the NPC as a representative body of the People's Democratic Dictatorship is downplayed in the study. 


\section{From Rubber Stamp to the 'Third Power Centre'?}

Contrary to the prevalent view that representative assemblies in communist countries are no more than rubber-stamp organizations, deprived of the real power of policy-making (Skilling 1973: 96), scholars generally agree that the People's Congress (PC) in China has begun to perform some concrete functions since the 1980s, when the country reversed its development course by adopting an open-door policy and reforming its economy. One Hong Kong scholar even goes so far as to suggest that the PC has become 'a third power centre' in addition to the Communist Party and the executive branch of Government (Wu 1999: 32738). Some recent studies on the PRC's legislative establishments concentrate on the PC's new autonomy and assertiveness (Nathan 1996; O'Brien 1994, 1998, 1990a, 1990b, 1988), especially in the area of lawmaking and the decrease in the Communist Party's control over the legislative organ (Tanner 1994, 1995). Other studies are attracted by PC's institutionalization (O'Brien 1990; McCormick and Unger 1996), or they discuss the opposition and contention that PCs have manifested while in session (Solinger 1982), or stress the importance of PC's representation (O'Brien 1998; McCormick and Unger 1996: 36-38). One topic conspicuously missing from the academic discourse has been the representative assembly's supervisory power.

Owing to the Communist Party's overwhelming dominance, the supervisory power has been considered either as being 'seldom exercised' (Nathan 1996: 49) or as having an uneven record unworthy of further study (O'Brien 1994: 97). This article argues that a new round of political reforms has quietly started at the provincial legislatures and that PCs, especially those at the provincial level, have managed to develop rights to check the executive administration and to some extent the Party itself. And these locally initiated reforms have often become part of the reformation drive at the central level after their effectiveness has been proven. This is not happening, moreover, at the expense of Party authority; on the contrary, this change has been underwritten by the Party itself and the Party has benefited accordingly, with its authority enlarged and bolstered.

With the mounting need for the rule of law and anti-corruption measures, and in view of the fact that PCs and People's Congress Standing Congress (PCSCs) have in the past been largely inactive for structural reasons, specialization in the legislature in the form of a differentiation in committees and subcommittees has become a political exigency. As a newly invigorated set of institutions still struggling to define their po- 
sition, the PCs are nevertheless weak in the triad of power distribution vis-à-vis the other two institutions-the Communist Party and the executive branch of the government. What has been germinating in the legislative bodies is that both of the specialized committees are groping constantly for more responsibilities as well as a powerful and centralized leadership. The trends of specialization and centralization of leadership have contributed not only to the rise of oversight in the previously insipid legislative assemblies, but also to a redistribution of power in the local political arena. In the end, the central government often is forced to adopt a bottom-up approach and continue reforms initiated and experimented with at the local level.

\section{Specialization, Differentiation and the Growth of Committees}

It has been argued that control of the administration is one of the most important functions of legislative bodies in all modern democracies (Loewenberg et al. 1985). The value of legislative monitoring of the executive branch, many contend, is to ensure the triumph of representative government by lines of accountability running through the organ that embodies popular sovereignty. Therefore, representativeness rather than effectiveness is the irreducible core (ibid.: 546). The perceived goals of legislative oversight are to check dishonesty and waste, guard against harsh and callous administration, evaluate implementation in accordance with legislative objectives, and ensure administrative compliance with statutory intent (ibid.: 547).

In his seminal work on the US Congress, Samuel P. Huntington (1990) concluded that structurally this organ has become more specialized with less leadership since its creation. The tendency of the weakening of central leadership and the dispersion of power to the committees have shifted the function of the US Congress to that of oversight. Other studies confirm the theory that knowledgeable oversight is being promoted by committee and subcommittee layouts. It is further contended that members' aspirations tend to strengthen committee government at the expense of executive autonomy and, to some degree, of party discipline (Loewenberg et al.1985: 556)

Committees have existed intermittently in China's NPC since 1954, when the first constitution was promulgated, but without great effect. Committee members could not 'thoroughly, specifically, and rigorously' examine financial matters, nor did they take part in drafting legislation or oversight (O'Brien 1988: 364-65). The 1979 constitution used the term 
'special committee' (zhuanmen weiyuanhui), for the first time, a phrase that was retained in the 1982 constitution. In February 1979, the NPC set up a Committee on Bills and Proposals and a Committee on Minorities with the authority of drafting and revising regulations. ${ }^{1}$ The 1982 constitution further set up six permanent committees on Law; Nationalities; Finance and Economics; Education, Science, Culture, and Public Health; Foreign Affairs; and Overseas Chinese Affairs. These committees gained the right to draft legislative proposals and to examine bills and inquiries referred by the NPC or NPCSC (O'Brien 1994: 365). In April 1988, one more committee-the Committee on Internal and Judicial Affairs-was created. In March 1993, the Committee on Environment Protection was set up at the Eighth NPC Congress. ${ }^{2}$ Finally, at the Ninth NPC Congress in March 1998, the Committee on Agriculture and Villages came into existence. Since 1988, all NPC committees have enacted their own organic rules and in addition to the permanent (or special) committee, the NPC also has ad hoc committees and provisional committees. The Preparatory Committee for the Special Region of Hong Kong, set up by the NPCSC in January 1996 in accordance with authorization from the NPC, was designed to cope with the legal aspect of Hong Kong's reversion to China.

Though a late development, the committees have rapidly emerged as the core of the NPC. At the Sixth NPC meeting held in 1983, leaders decided that bills must be sent to the Law Committee or relevant committees for review after the first reading. This heralded the arrival of the legislative reading system and six committees were created as a result. The new development also effectively changed the old legislative process in which the NPCSC took the central seat. The year 1986 was pivotal in terms of specialization when Chen Bixian, an NPC vice chairman, announced that the six committees were to become a permanent part of the NPC institution. At the same time, it was decided that those NPCSC members residing in Beijing should, in principle, join committees. A reinforcement plan was executed when over 40 members of the NPC Standing Committee were assigned to committee responsibilities, constituting 63 percent of the entire NPCSC membership committee members. At the Seventh NPC meeting held five years later, the number rose to 80 percent. Ever since the Eighth NPC meeting, virtually all NPCSC members-save the chairman-have joined committees. This is a significant increase compared with the first three NPC Congresses held in the 1950s and 1960s, when the NPCSC members were a rarity in the two committees. ${ }^{3}$ 
Instead of ideologues, committee members are now almost exclusively former government functionaries, party secretaries, State Council officials, researchers, provincial leaders, and representatives of the major mass organizations, including the Chinese Women's Federation, Workers' Federation, and Youth Corps.

Along with institutionalization, professionalization has been a conspicuous component of legislative development. Nelson Polsby stated that the internal complexity of the US Congress can be measured by growth in the autonomy and importance of committees, in the growth of specialized agencies of party leadership, and in the increase in the provision of various emoluments and auxiliary benefits to members in the form of office space, salaries, allowances, staff aid, and committee staffs (Polsby 1968: 153).

TABLE 1: Membership Development of the NPC Committee

\begin{tabular}{|l|c|c|c|c|c|c|c|c|c|}
\hline Committees & $\begin{array}{c}\text { 1st } \\
\mathbf{1 9 5 4}\end{array}$ & $\begin{array}{c}\text { 2nd } \\
\text { Sept. } \\
\mathbf{1 9 5 4}\end{array}$ & $\begin{array}{c}\text { 3rd } \\
\text { April } \\
\mathbf{1 9 5 9}\end{array}$ & $\begin{array}{c}\text { 4th } \\
\text { Jan. } \\
\mathbf{1 9 6 5}\end{array}$ & $\begin{array}{c}\text { 5th } \\
\text { Jan. } \\
\mathbf{1 9 7 5}\end{array}$ & $\begin{array}{c}\text { 6th } \\
\text { June } \\
\mathbf{1 9 8 3}\end{array}$ & $\begin{array}{c}\mathbf{7 t h} \\
\text { April } \\
\mathbf{1 9 8 8}\end{array}$ & $\begin{array}{c}\mathbf{8 t h} \\
\text { March } \\
\mathbf{1 9 9 3}\end{array}$ & $\begin{array}{c}\text { 9th } \\
\text { March } \\
\mathbf{1 9 9 8}\end{array}$ \\
\hline Minorities & 85 & 84 & 114 & - & 81 & 14 & 22 & 25 & 23 \\
\hline Law * & 33 & 37 & 41 & - & 36 & 13 & 21 & 18 & 29 \\
\hline $\begin{array}{l}\text { Internal and } \\
\text { Judicial Affairs }\end{array}$ & - & - & - & - & - & - & 20 & 19 & 20 \\
\hline $\begin{array}{l}\text { Finance and } \\
\text { Economics }\end{array}$ & - & - & - & - & - & 14 & 28 & 29 & 21 \\
\hline $\begin{array}{l}\text { Education, Science, } \\
\text { Culture, and } \\
\text { Public Health }\end{array}$ & - & - & - & - & - & 17 & 30 & 31 & 34 \\
\hline Foreign Affairs & - & - & - & - & - & 10 & 18 & 15 & 15 \\
\hline $\begin{array}{l}\text { Overseas Chinese } \\
\text { Affairs }\end{array}$ & - & - & - & - & - & 9 & 17 & 21 & 16 \\
\hline $\begin{array}{l}\text { Environment } \\
\text { Protection }\end{array}$ & - & - & - & - & - & - & - & 17 & 21 \\
\hline $\begin{array}{l}\text { Agriculture and } \\
\text { Villages }\end{array}$ & - & - & - & - & - & - & - & - & 26 \\
\hline
\end{tabular}

*The committee was named the Committee for Bills and Proposals for the 1st, 2nd, and 3rd NPC Congresses. The name was kept when the committee was resurrected in 1979. Since the 6th NPC Congress, it was renamed the Law Committee.

Sources: Quanguo renda changweihui bangongting yanjiushi (ed.) 1990; NPCSC

Communiqué, 1991-98. 
TABLE 2: The Changing Nature of the NPC Special Committees

\begin{tabular}{|c|c|c|l|}
\hline Congress & $\begin{array}{c}\text { No. of } \\
\text { Committees }\end{array}$ & $\begin{array}{c}\text { \% of NPCSC } \\
\text { Membership }\end{array}$ & Newly-acquired powers \\
\hline 6th & 6 & 63 & $\begin{array}{l}\text { Jurisdiction of committees delineated; } \\
\text { legislative review; reading system; } \\
\text { investigation; becomes permanent institution; } \\
\text { NPCSC meeting rules enacted }\end{array}$ \\
\hline 7th & 7 & 80 & $\begin{array}{l}\text { Auxiliary institution created; right to hear } \\
\text { government reports; committee organic rules } \\
\text { enacted; interpolation; legal inspection; } \\
\text { subcommittees formed; NPC meeting rules } \\
\text { enacted }\end{array}$ \\
\hline 8th & 8 & $\begin{array}{l}\text { Nearly the entire } \\
\text { membership }\end{array}$ & Joint legislative review; more legislation \\
\hline 9th & 9 & $\begin{array}{l}\text { Nearly the entire } \\
\text { membership }\end{array}$ & \\
\hline
\end{tabular}

Source: Chien-min Chao and Chang Chun-hsiang 2000: 195.

TABLE 3: Expanding Powers of the NPC Committee

\begin{tabular}{|c|c|c|c|c|}
\hline & \multicolumn{2}{|c|}{ Bills Reviewed } & $\begin{array}{l}\text { Government Work } \\
\text { Reports Heard }\end{array}$ & $\begin{array}{l}\text { Laws Passed and } \\
\text { Amended }\end{array}$ \\
\hline NPC & Committees. & NPCSC & NPCSC & NPCSC \\
\hline $\mathbf{1}$ & & 0 & 40 & 35 \\
\hline $\mathbf{2}$ & & 0 & 86 & 7 \\
\hline $\mathbf{3}$ & & 0 & 23 & 3 \\
\hline $\mathbf{4}$ & & 0 & 2 & 19 \\
\hline $\mathbf{5}$ & & 0 & 63 & 42 \\
\hline $\mathbf{6}$ & & 137 & 65 & 48 \\
\hline $\mathbf{7}$ & & 168 & 69 & 75 \\
\hline $\mathbf{8}$ & 566 & 273 & 65 & 19 \\
\hline
\end{tabular}

Sources: Liu, Yu and Cheng 1991; Yang 1997: 321-36.

In the case of China, not only has the number of standing committees increased steadily, but subcommittees have also been created to help with drafting and reviewing responsibilities assigned to the committees. Legislative hearings have been introduced in the process of legislative deliberation. New ad hoc institutions have been formed within the Party to help with the work of PCs.

It was decided in 1983 that a bill would have to be sent to the Law Committee or relevant committees for review after first reading. However, the NPCSC Meeting Rules passed in 1987 and NPC Meeting Rules 
in 1989 require that all bills in the NPC and NPCSC be reviewed by the Law Committee and relevant committee(s) simultaneously. In order to better understand the feasibility of bills, the Law Committee in June 1984 started an investigation into the reviewing of bills. Since then, legislative investigation has become an important and integral part of the committee's legislation.

TABLE 4: NPC Committee Structure

\begin{tabular}{|c|c|c|c|}
\hline NPC & No. of Committees & Size & New Committee(s) \\
\hline $\mathbf{1}$ & 2 & 118 & - \\
\hline $\mathbf{2}$ & 2 & 121 & - \\
\hline $\mathbf{3}$ & 2 & 155 & 2 \\
\hline $\mathbf{4}$ & - & - & 4 \\
\hline $\mathbf{5}$ & 2 & 117 & 1 \\
\hline $\mathbf{6}$ & 6 & 77 & 1 \\
\hline $\mathbf{7}$ & 7 & 158 & 1 \\
\hline $\mathbf{8}$ & 8 & 175 & 205 \\
\hline $\mathbf{9}$ & 9 & 2 & . \\
\hline
\end{tabular}

Sources: Quanguo renda changweihui bangongting yanjiushi (ed.)1990; NPCSC communiqué, 1991-98; Quanguo renda changweihui bangongting yanjiushi (ed.) 1998: 214-15.

Legislative hearings or lunzheng (to discuss and substantiate) first begin as meetings and then seminars are held. Usually a bill is reviewed by the Law Committee and a relevant committee at the same time (Tanner 1995). Committees have the power to decide whether lunzheng is necessary. The procedure is as follows: after being briefed by the drafter at a plenary meeting at the NPCSC, a bill is sent to the Law Committee and a relevant special committee for review. The Law Committee then sends the draft bill, as a required step, to the Provincial People's Congress (PPC), the minorities' autonomous regions, concerned departments at the central government (National People's Consultative Conference, the Supreme Court, the Supreme Prosecutor's Office, relevant departments of the State Council, the Chinese Federation of Unions, Chinese Federation of Women, and the Youth Corps) for advice. The Law Committee also decides, according to the importance and conten- 
tiousness of the bill, if a hearing (lunzheng) is needed. For an ordinary standing committee, the first half of the legislative investigation is missing, but lunzheng is often exercised when bills are examined.

Although a bill is examined simultaneously by the Law Committee and a relevant committee, the effectiveness of the opinions expressed do differ. For ordinary committees, the opinions are given, in printed copies, to members of the NPC, NPCSC and the Law Committee for reference. It is the Law Committee that has the ultimate power of deciding whether to incorporate those opinions and bring them to the attention of the Praesidium of the NPC or the NPCSC plenary meeting. Without this procedure of tongyi shenyi (to examine indiscriminately), ${ }^{4}$ a bill is not allowed to progress to the second reading. The role of the Law Committee is especially significant for the NPC owing to its large size and short meeting time (only a couple of weeks per annum). Because of the issue of duplication and redundancy (that is, a bill being reviewed by two committees at the same time), the Committee on Internal and Judicial Affairs started to work with the Law Committee in 1994, thereby ushering in a new era of joint hearings and deliberations.

Publication in the mass media is often required for major bills to seek responses from the masses. The opinions solicited are periodically printed in a newsletter Fazhi gongzuo bao [Newspaper for Legal Work], published by the Working Committee on Legal Affairs, a supporting institution under the NPCSC, and forwarded to the NPCSC and its leadership, members of the Law Committee, and relevant agencies of the central government. One case that stands out is the Contract Law passed at the Eighth NPC Congress. Altogether there were 12 universities and research institutes that took part in the drafting process. Another example is the Company Law, where 210 agencies or departments were consulted before the bill passed into law (Quanguo renda changweihui bangongting yanjiushi (ed.) 1998: 24).

Since the idea of a market economy was imported from overseas, foreign experience is often sought in the enactment of economic legislation. Outside influence can be detected in laws such as the Company Law, Accounting Law, Law for Commercial Notes and Checks, and Law to Prevent Improper Competition. In addition, the Litigation Law, the Law for Civil Administration, and the hearing system in the administrative punishment bear the hallmarks of a non-indigenous legalistic influence. 
To cope with the increasing diversity of legislation, some localities have gone one step further by setting up advisory boards to help with drafting. The Law Committee of the Chongqing People's Congress has a panel of 29 legislative consultants, and most of these legislative assistants are professors at Southwestern University of Politics and Law, among them four professional lawyers. When the Chongqing PC proceeded with the task of evaluating the 24 laws one year after enactment in 1999 (a practice started in 1986 when the Organic Law of the Local Government was amended), 12 of these legal advisors were asked for assistance. $^{5}$

Structurally, NPC committees have been growing in number as well as in membership. In the first two NPC congresses, the two committees-the Committee on Minorities and the Committee on Bills \& Proposals-had a joint membership of 118 . The fact that racial equality was upheld as one of the founding tenets of the new republic had a lot to do with the impressive size. When the same two committees were resurrected in 1979 (as the Committee on Nationalities and the Law Committee), the tradition was basically kept. The large size warranted the symbolic status of the committees. When four additional committees were created in 1983, the size was drastically reduced with a combined membership of 77 for all six committees. With the addition of three new committees and enlarged functions, the number increased nearly threefold to a total of 205 at the Ninth NPC.

In yet another move of further differentiation, subcommittees have also been brought into existence. The increasing demand for legislation and the infrequent and short meeting times for the committees (once a month for a meeting that lasts no more than a couple of days) are two reasons behind the rise of the new organizations. There are two kinds of subcommittees at present: ad hoc and permanent. A subcommittee, or a xiaozu (small group), can be formed if deemed necessary by the committee. The organic rules of the Committee on Finance and Economics and the Committee on Education, Science, Culture, and Public Health allow such a formation (NPC Committee on Internal and Judicial Affairs 1992). Since 1989, two subcommittees- the Group on Women's and Children's Affairs and the Group on Adolescence-were created on a permanent basis under the jurisdiction of the Committee for Internal and Judicial Affairs. Ever since then, strengthening the functions of the subcommittees has been one of the central tasks of the NPC reforms. 
The Group on Women's and Children's Affairs has a membership of 22 while the Group on Adolescence has 27. A close scrutiny of the structures of the two groups substantiates professionalization as the central principle of organization: only a paltry 18 percent of the aggregate membership are NPCSC members while the remaining 82 percent are outside recruits with expertise (Zhou 1998: 78). The subcommittees have the power to review bills and proposals, to propose motions and bills, and to research issues of concern and come up with solutions. Alternatively, a legislative group may also function solely as an advisory body to the special committees or as a frontline reviewer of bills and proposals, as is the case of the Committee on Finance and Economics.

\section{Centralization of Leadership}

The centralization of leadership in the legislature is also considered more appropriate to meet the needs of the modern environment. A centralized leadership can forge closer connections between the legislative institution and major external forces and groups. While dispersion of powers to the committees is definitely a new development in China's People's Congress system, the past Leninist tradition of party-state dictatorship has certainly helped in forging a strong leadership in the legislative assembly.

The head of the PCs is in many ways a powerful position. Li Peng was the Number Two man in the CCP hierarchy. Directors of LPCs most likely also hold the post of secretary of the local Party committee. The chairmanship group meeting is a very important forum in formulating the NPCSC agenda and in screening bills and proposals. In a typical directorate group meeting for an LPC, the agenda is basically set by the permanent committees-a sign of the importance of the committees. The chairmanship group meeting is composed of the NPCSC chairman and vice chairmen (up to 19 in number) and the secretary-general. Theoretically, decisions are reached collectively and the chairman refrains from making unilateral decisions. In reality, though, the power of the chairman/director is very much dependent on the stature of the individual. This is especially the case after a directive was passed down recently demanding that all the local party secretaries concurrently serve as LPC directors. As such, a dominant party secretary can almost single-handedly dictate the agenda. ${ }^{6}$

The chairman of the NPCSC and the directors of the LPCs wield tremendous statutory as well as hierarchical power within their organizations. They can revise the opinions expressed by the committees in their 
reviewing of bills and proposals. The chairman also wields a lot of influence in setting the committee agenda, by initiating an investigation into the process of legislative review, deciding if a proposal should be tabled, and determining if a bill should go to the Law Committee or other relevant committee. In addition to these statutory powers, the opinion of the chairman carries much weight in terms of personnel management for those associated with the PCSCs. The fact that only about one half of the LPCSC membership work full-time and the meetings of the PCSCs last no more than a few days have also rendered additional powers to the chairmanship.

According to the Organic Law, the NPCSC chairman is charged with coordinating the day-to-day work of the legislative body as well as its special committees. The same regulation is vague, however, as to what exactly constitutes the daily work, nor is the chairman held accountable to the NPCSC or otherwise under its supervision. In some provinces, the director alone is responsible for setting the entire agenda of the PCSC meetings and some directors are even granted power to permit the arrest or to detain deputies by law enforcement agencies, provided that the decision is later sent to the chamber for approval. The opaqueness of the stipulation evidently gives the chairman more liberty in this capacity. The fact that many of the LPCs directors are also the secretary or deputy secretary of Party committee has bolstered the chairmanship vis-à-vis that of the PCs as an institution. A case in point is Li Peng. Li was slighted in his capacity as premier in the State Council, but has been acclaimed as one of the most productive chairmen in NPC history. His past experience as premier and the fact that he outranked Zhu Rongji (former premier) in the CCP has definitely enhanced Li's credentials. ${ }^{7}$

Party-state political tradition and the institutional design have led some observers to the conclusion that the chairmanship group may become an 'authoritative and efficient organ of power' and a base for the chairman to expand his influence. Some even go so far as to suggest that the chairman may become a 'formidable political figure,' perhaps even one of the four pre-eminent leaders in an interlocking party-state directorate and that the NPCSC is a 'legislature-within-a-legislature.' (Cheng 1983; O'Brien 1988: 364; Weng 1982). It is common now to place the PC meetings, PCSC meetings, and the directorship group meetings on a par and collectively address them as the three meetings of the LPCs (Zhang Yuankun 1997:1). 
It was decided at the Sixth NPC meeting that to facilitate effective functioning, the committee chairmanship should be concurrently served by the vice chairmen of the NPCSC - the committee vice chairman would also have to be a member of the NPCSC. Since the Eighth NPC, however, NPCSC vice chairmen no longer serve as committee chairmen. When the committee is not in session, it is the committee chairmanship group - composed of the committee chairman and vice chairmen (numbered four to six) - that makes the decisions on behalf of the committee. The committee chairmanship group meets once every month and committee vice chairmen form the Committee Office Work Meeting (weiyuanhui bangong hui). The meeting is held once every two weeks to discuss day-to-day affairs. The work of subcommittees is also coordinated at the meeting. Committee chairmen and vice chairmen are forces to be reckoned with as they have the final word in the deliberations by the committee regarding a bill or proposal. The chairman is usually the agenda-setter for the committee and he can also participate in the NPCSC chairmanship group meeting and express opinions on behalf of the committee. Committee and vice chairmen are also the most important factors in the positioning and repositioning of personnel in the committee.

\section{Legislative Oversight}

The legislative oversight of the NPC has been developed in line with its institutionalization and specialization, and again it is local legislatures that took the initiative. In 1984, in a law approved by its PCS-the Provisional Regulation on the PCSC's Work - the city of Tianjin first legalized the work of legislative oversight. Now almost all provinces have similar enactments (Zhang Wei 1996: 64). Although a draft of the supervisory law has been contemplated by the NPC for quite some time, its passage is still not in sight. Among the supervisory powers that the PCs have invented, the most effective have been the pingyi, a measure to evaluate and discuss the work of government agencies and officials, and zhifa jiancha, inspection on the implementation of laws.

Nanan Prefecture People's Congress of the city of Chongqing organized deputies in 1984 to review the work of officials approved by the Congress, however superficial, upon appointment. The system has quickly spread to other places and, in many cases, been made into law. In November 1991, marking acceptance of the excellent method developed from below, a meeting was convened by the NPC Committee on 
Internal and Judicial Affairs to summarize experiences of the pingyi. The new tool subsequently won acclaim by NPC Vice Chairmen Peng Chong in 1992 and Tian Jiyun in a work report to a NPC meeting in 1995 (Du 1998: 59-60).

Pingyi can be used to inspect the work of government departments (gongzuo pingyi) or officials whose appointments need PC approval (shuzhi pingyi). It can be aimed at a specific policy implemented by the government or at the work of a xitong (system). ${ }^{8}$ It can be carried out at a single level of the bureaucratic hierarchy or at all levels of the government from the province down to the township (xiang). It can be implemented by PC delegations, or by the PCSCs, the committees, or the PCs.

A pingyi motion can be initiated by deputies, PC delegation, special committees, or the directorate group meeting. It can also be proposed by the masses. Once a motion is approved by the directorate group meeting and concrete proposals framed, a pingyi leading group is established, led usually by the director or a deputy director, composed of a few members selected from the PCSCs and PC deputies. Relevant committees are the driving force throughout the entire process. At the second stage, members of the investigation team have to engage themselves in an educational and self-learning session, where relevant laws and regulations are studied. At the third stage, an investigation is carried out. The pingyi group travels to the targeted department and holds a plenary meeting, attended by all employees as well as officials, and goals of the inspection are pronounced. Interviews are conducted with the employees of the targeted department, employees working at concerned agencies, and selected masses who had dealings with that particular department. Documents are reviewed and confession sessions held. At the fourth stage, a pingyi meeting is held to ping (to criticize) and $y i$ (to opine) the targeted. Opinions organized by the inspection group are expressed at the plenary meeting in which employee attendance is required. At the fifth and final stage, the targeted department is required to come up with a written proposal of rectification within a month and report in writing the results to the PCSC within two to six months. The pingyi leading group then pays another visit to the targeted department to check up on the situation. If the results are less than satisfactory, then compulsory measures may be considered.

Over the years, the law enforcement agencies-the so-called zhengfa xitong (political-legal system) - have been the prime targets of gongzuo pingyi. The reason for the emphasis is simple-to fight corruption. Al- 
most all provinces have launched pingyi inspections in the past few years to oversee the work of the police, the prosecutor's office, and the court system. The commerce and taxation departments also have become priorities. Because of the scale of people mobilized in the process, normally gongzuo pingyi is carried out once a year.

On the other hand, officials subject to shuzhi pingyi, usually in the form of being given a work report by the requested official, have been extended to include those whose appointments need approval from the PCs, including heads of the departments and agencies and sometimes deputy provincial governors. In addition to inquisitions, this group of officials may sometimes face a written examination, conducted by the Law Committee or Committee on Legal Work (a supporting institution working for the PCSCs rather than a special committee), before getting approval from the PCSCs.

PCs at different levels have enacted hundred of laws and regulations, ${ }^{9}$ however, the implementation of those legal documents has been less than comprehensive. It is estimated that only 15 percent of the laws enacted have been faithfully implemented (Zhang Yuankun 1997:39). Consequently, zhifa jiancha (inspection on the implementation of law) has emerged as one of the major elements of PCSC oversight in the past decade.

Heralding the much-touted new practice, the LPCs were given the power to supervise the implementation of the constitution as well as laws when the Organic Law of Local People's Congress and Local People's Government (hereafter Organic Law) was amended in 1986. NPCSC, collaborating with PCs down the line, carried out inspections of over 21 laws and relevant legal decisions made at the Eighth NPC session between 1993 and 1998, while its committees inspected twice as many in the same period (Quanguo renda changweihui bangongting yanjiushi 1998: 33-34).

According to the law 'Some Regulations on the Improvement of Inspections of the Implementation of Law', ratified by the NPCSC in 1993, zhifa jiancha seeks to tackle 'major problems engendered in the process of socialist modernization' and other 'issues strongly expressed by the masses. ${ }^{10}$ For the sake of specialization, legislative committees have once again become the backbone of newly acquired power.

Much like pingyi, zhifa jiancha was a local initiative, developed out of the need to combat vices brooked in the modernization of the socialist economy. As also is the case with pingyi, zhifa jiancha is not exempt from the strong tradition of mass mobilization inherited from a former 'move- 
ment regime'. ${ }^{11}$ Once a law is targeted, a task force is formed. The inspection team is headed by one of the deputy chairmen/directors of the NPC/PCs, with members of the PCSCs constituting its bulk. An education session and then investigation soon follow, while masses are mobilized and meetings held. To underscore the importance of legality and broaden its effects, propaganda is emphasized. In an inspection organized to check the efficacy of the laws related to the work of the legal-political system, the Putien PC, in a small city located in the vicinity of Fuzhou, launched a 'big discussion' session to 'erect viewpoints of the masses and to enforce the laws rightfully and in a civilized way'. Telephone numbers were advertised in the press. A reception office was created to receive those who wanted to come and relay their stories. As it turned out, 221 letters along with 243 visitors were received with over 100 cases being raised. At the end, 56 cases were selected and relayed to corresponding agencies for reference (Zhang Yuankun 1997: 42). In what is known as a strategy of shangxia liandong, a vertical mobilization of PCs, targets are broadened to maximize effect.

As in the case of pingyi, the most critical phase of the zhifa jiancha lies in 'rectification and improvement' (zhenggai). Criticism and self-criticism are heavily involved. Interpolation, investigation and removal from duty are possible means at the sponsor's disposal. The Supervision Act passed by the Guangdong PPC in 1994 stipulated that a 'legal supervisory paper' with the signature of five PCSC members and approved by the directorate group meeting can be issued to an official guilty as charged. The official is obliged to report to the PCSC within a specified timespan or must face punitive actions. ${ }^{12}$ Here again, a political reform process starting from below and slowly working its way upward is discernible. After being introduced by local PCs in 1986, the Seventh NPC (1988-93) and its Standing Committee incorporated and brought the practice to the central government. During that period, in cooperation with LPCs, the NPCSC and its committees organized 53 inspection tours with 31 laws and six legal decisions targeted for inspections (Zhang Wei 1996: 57).

\section{New Party-Executive-Legislative Relations}

While many believe that the there is an institutional decentralization of party control over law-making (Tanner 1994: 384-88) and a growing weakness of the Chinese apparatus of the state (Scalapino 1993) there is no academic discourse on the changed executive-legislative relations. The invigorated legislative oversight is bound to herald a new era for 
the bilateral relationship between the two branches of the government. Rather than being stymied in the party-state dyad, the new relations have begun featuring a limited accountability in the previously rigid political system. An institutionalized channel of communications has been established between the Party and the two branches of the government. Now it is routine for government officials to be present at meetings held by the PCSCs. To avoid superficiality, some PPCs even require heads of the government (rather than their deputies) to take part in these sessions and give the work report. A new development has been that the government work report, instead of being distributed and reviewed in its entirety, is broken into several reports in accordance with their nature and then reviewed by different groups of deputies organized by their spheres of interest and specialization. The new division of work is basically being drawn in line with the legislative committees such as Finance; Legal Affairs; Agriculture \& Forestry; Municipal Construction; Education, Science \& Culture, etc.

Since 1991, the PC of the city of Chengdu decided to request reports on those subjects most discussed by its citizens. A feedback system has also been established by many PCs so that the executive branch is forced to respond to decisions and resolutions adopted by the PCSCs and to opinions expressed after reviewing a bill. The Huchen County PC has come up with a tracking system, whereby the opinions expressed by its PCSC after reviewing a proposal are written in a cuebanka (a memorandum for action) and signed by the office director of the relevant legislative committee or by the committee vice chairman in charge of the investigation. The memorandum is then forwarded to the executive branch. The official who holds the ultimate responsibility for the case, the head of the government or his deputy, is required to give a progress report to the PCSC at the next session. Normally a case is allowed a three-month grace period with an additional three months for particularly difficult ones. In the end, the memorandum has to be co-signed by the responsible official and returned to the PCSC for conclusion (Zhang Yuankun 1997: 12).

Another innovation that is reshaping executive-legislative relations is the creation of liaison offices. In Dague County, Liaoning Province, a deputy county magistrate designated as the liaison officer meets every quarter with his counterpart (a deputy director at the PCSC) to discuss issues of mutual concern. Heads of the county's PC are invited to the magistrate's work meeting and the government work meeting. A reso- 
lution entitled 'Regarding the Serious Acceptance of PC Supervision' was passed by the county government to show deference to the PC work (Zhang Wei 1996: 66). It is now common practice after each LPC session for the executive branch to convene meetings to reflect motions and proposals previously raised at the legislature.

The country's economic performance over the last two decades has led some observers to conclude that China is capable of transforming its Leninist political system and discarding Marxism-Leninism in favour of a 'developmental nationalism.' (McCormick and Unger 1996: 2). While decisions over important matters are still made by the Party, the Party is said to involve itself less with the day-to-day administrative duties while the legislature is used as a proxy (O'Brien 1989: 62). Another observation is that the Party is decentralizing its control over law-making (Tanner 1994: 384-88). An interesting development is that the Party is actually gaining strength by delegating powers to the legislature.

The Party has been the most important supporting as well as inspiring force behind the new expansion of supervision, but ironically, it is also the biggest deterrent. As early as 1994, former NPC chairman Peng Zhen demanded that local party committees at all levels discuss the PC work on a regular basis. In a decree entitled 'The Party Must Resolutely Maintain Socialist Legality', released in July 1986, the Party asked all its cadres to recognize the importance of the legality and support the work of the PCs and their resolutions. On the other hand, an equal number of resolutions have been passed by the Party demanding stronger leadership over the PCs. The resolution entitled 'A Decision to Strengthen the Linkage between the Party and the Masses' which was adopted at the Sixth Central Committee Plenary Meeting of the Thirteenth Party Congress held on March 1990, is one example. Consequently, what has emerged is not a weaker party leadership in the legislature, as some have suggested (Tanner 1994: 384-88). On the contrary, while being involved less with day-to-day legislation, the Party has nonetheless strengthened its leadership at the legislative chamber level, with its communication network having been revitalized.

The new Party-legislative relations are as follows. First, local Party committees regularly convene meetings, with representatives from both the executive and legislative branches attending, to co-ordinate work in the sphere of the political-legal xitong and to mobilize support for the legislature. Before each pingyi, zhifa jiancha, and inspection mission is launched, the Party organization within the PCSC (the dangzu)—com- 
prised of the PCSC director, deputy directors, and secretary-general who are also members of the Party-has to report the plan to the Party committee at the same level in detail and ask for approval and endorsement.

\section{Limitations}

The increasing specialization and the embryonic oversight function that the PCs possess have fundamentally changed Party-executive-legislative relations. Some even argue that this change may gradually lead to a system that would essentially render a mighty Communist Party to be checked and balanced to some extent by the legislature. ${ }^{13}$ This argument seems valid at first glance. Despite the fact that the Party still enjoys overwhelming control over the nomination and management of cadres, those at the second tier of officialdom have to face interrogation before appointment and, sometimes, downright rejection. ${ }^{14}$ These officials occasionally face scrutiny after assuming office as well. There is no doubt that the Party is gradually easing out of the day-to-day decisionmaking in the new political machinery, leaving the executive branch responsible for daily operations. The Party's retreat has also paved the way for the surge in legislative power. Through mechanisms (mostly newly-invented or resuscitated) including interpolation, pingyi and legal inspections, the LPCs are no longer powerless institutions.

As Anthony Dick observes, the legal system in China remains a tool of the CCP (Dick 1989: 542). The party-state conglomeration is still in place, and the closer one is to the bottom of the bureaucratic hierarchy, the worse the situation gets. What we have is a new party-state system in which the Party no longer makes all the decisions. Organizationally, the overwhelming overlap between the party and the state characterized by the old Leninist party-state system is now a thing of the past. It was not unusual previously for the Party organization to be staffed more than the administration of the organization. Today, the Party remains strong, but is much smaller in size relative to that of the state. Notwithstanding, the Party's dominance remains supreme. For example, nearly one-third of the PPC chairmen in 2000 were also concurrently secretaries of the Party committees (http://www.peopledaily.com.cn).

The crux still lies in the Party and the issue is over the right of decision-making. The constitution and the Organic Law give the LPCs powers to decide on the 'vital issues' in areas including politics, economics, education, science, culture, hygiene, civil affairs and minorities. How- 
ever, decades of Stalinist tradition have moulded the Party as the ultimate and uncompromising source of vital policy-making. It has been suggested that 'vital decisions' be further divided into 'issues with overall implications' and 'with limited implications'. For issues like major reforms, development strategies, and large-scale construction projects, it is urged that the tradition of Party command be sustained. As for such matters as regional planning, educational reforms and the protection of the minorities, it is suggested that the Party had better step aside and provide leadership by guidance (Won and Fu 1991: 52). Despite academic discussion, major decisions are still reached through the Party machine. It is not uncommon for the Party to make decisions unilaterally and then forward them to the executive branch for implementation, thereby bypassing the legislature. Joint decrees between the Party and the executive remain problematic, rendering legislative oversight impossible. A laughable case often cited is the one issued jointly by the State Council and the CCP a few years back resetting the summer clock. Which commands supremacy, law or superior? The case remains open.

The permanent committees at the NPC and many PPCs have undoubtedly become key players in their institutions, but specialization there is still a goal to be fully realized. The nine committees in the NPC, although this represents a major step towards differentiation and specialization, are far from sufficient to be a national legislature for a country the size of China. Furthermore, the committee system is still under development and efforts are being made to allow them to function better. Besides, all legislative acts are subject to examinations by the Law Committee before being tabled by the Chairman's Meeting for readings. This practice has also cut the effectiveness of other committees.

At the provincial level, the committee is an even weaker institution. Among the 31 provinces, autonomous regions and municipalities, there are a total of 164 committees, with an average of 5.4 committees per province ${ }^{15}$ Among them, nearly three-quarters are 'working committees,' a weaker institution compared to the 'committees' both in statute and in reality, subject to the PCSCs rather than the PCs, while PCs at the lower levels hardly have any committees (Zhang Wei 1996: 78-79). As for the xiang and township PCs, a lack of standing institutions has nullified the PC institution as a whole. Lately, a new development has been the creation of a standing chairman at the praesidium and a full-time staff to handle daily affairs. 
Another major problem obstructing the legislative specialization has been a lack of professionalization. Two-thirds of the NPC committee members are newly recruited from its congress held once every five years. Usually those posted for the job at the PCs are cadres nearing retirement, as the average age for NPC committee membership is between 60 and 70. Some committees have less than half of their membership working full-time and many of them are living in places across the land mass of China. An institution staffed with a 'second line of cadres', which meets no more than a couple of days per month, is not going to be taken that seriously. At the provincial level, full-time PPCSC members usually constitute a little less than half of the entire membership. It is no wonder that a lot of important policies made by the Party or the administration are not brought to the PCs for approval. The rights of interpolation and acquisition, investigation and dismissal are also rarely utilized in many places. It is not uncommon for the officials who are required by law to be present at the PCSC meetings to refuse to show up. This recalcitrance has prompted some county PCs in Shandong and Hubei to adopt stringent measures by refusing substitution when writing their government work reports (Zhang Yuankun 1997: 15-16).

Pingyi is another case in point. It has remained a local initiative. Many PPCs have started to review the work of the administrative and the judicial branches of the government and sometimes local officials are 'tested' before appointment. However, these practices remain primitive and their results mixed. Consequently, praise rather than censure is often the outcome of these 'inspections'.

\section{Conclusion}

While the attention of China studies has focused on grassroots elections (a practice that has effectively remoulded the lives of many villages), less attention has been paid to developments in legislative transformation, especially at the provincial level. However, the urbanization and the structural and institutional changes undergone in China in the past two decades have been nothing short of spectacular. To redress the malfeasance brought by the new decentralization of economic resources, PPCs are taking the lead in another round of incremental political reforms. This paper confirms the theories that legislative specialization is indeed an institutional adaptation to the complex needs of a new environment cultivated by the industrialization started by the late paramount leader Deng Xiaoping. 
Contrary to the experiences of many industrialized countries in the West, a centralized leadership has been retained in the Chinese legislature. The combination of specialization and centralization of leadership has led to an augmentation of legislative oversight. Measures developed by the legislative institutions, such as pingyi and zhifa jiancha, have enlivened the previously lethargic local political scene and given rise to the committee autonomy. These political reforms, though underpublicized, have transformed local politics, forcing the central government (the NPC) to follow suit. The urgent need for institutional mechanisms to counter the vices associated with socialist market reform has prompted the Party to turn its attention to the PCs. Consequently, a Leninist party-state system-one in which the Party constantly overrode the executive branch of the government and one in which the legislature was totally stymiedhas been transformed into a new system in which the Party is allied simultaneously with the executive and the legislative branches.

A preliminary and limited balance of power is now emerging in which the Party is not totally immune. The exclusive right to personnel management is challenged, though in a preliminary way, by the PCs in the name of legislative oversight. The newly acquired legislative powers have not only redefined the tenets of Party leadership, but have also rewritten its relations with the executive branch. Although the PCs are still often barred from vital decision-making, new devices such as pingyi and zhifa jiancha are forcing some local officials to have second thoughts before venturing too far from legal boundaries.

Dr Chao Chien-min is Professor at the Sun Yat-sen Graduate Institute for Social Sciences and Humanities, National Chengchi University, Taiwan.

\section{Abbreviations}

CCP Communist Party of China

LPC Local People's Congress

LPCSC Local People's Congress Standing Congress

NPC National People's Congress

NPCSC National People's Congress Standing Committee

PPC Provincial People's Congress

PC People's Congress

PCSC People's Congress Standing Congress 


\section{Notes}

1 The Committee on Bills and Proposals is one of the two committees (the other is Minorities) set up by the 1st, 2nd, and 3rd NPC. The NPC was destroyed during the Cultural Revolution period. When the committee system was revived in 1979, the name was kept, but it was renamed as the Law Committee in 1983.

2 The committee was renamed the Committee for the Protection of Environment and Resources in 1995.

3 There were 3, 4, and 15NPCSC members that joined the two committees, Law and Minorities, at the three congresses (Zhou 1998: 34).

4 'Tongyi shenyi' is stipulated in Article 24 of the NPC Meeting Rules and Article 16 of the NPCSC Meeting Rules.

5 Author's interview with Chongqing PC's senior legislators in July 2000.

6 Author's interview with personnel working with the Zejiang PC.

7 This opinion is shared by almost all the scholars and local legislators whom the author has interviewed in many places across China over the past few years.

8 Chinese use the term 'system' to divide bureaucracies into different groupings ( see Lieberthal 1995: 194-207). According to Lieberthal, there are six major xitongs. The six-xitong divide is basically confirmed by Yan Huai, but with slight differences (see Yan 1995: 39-50).

9 During the Eighth NPC session (1993-1998), 85 laws and 33 legal decisions were approved. In the same period, 4,200 local regulations were approved by the NPC also. See Quanguo renda changweihui bangongting yanjiushi 1998: 2-7.

10 The stipulation can be found in A Handbook for the Work of PC Oversight edited by NPC Committee on Internal and Judicial Affairs 1996.

11 Some scholars use the term 'movement regime' as a substitute for the totalitarian regimes, because of their inclination and love for mass mobilization and political movements (Tucker 1967: 343-58).

12 Article 13 of the Act (NPC Committee on Internal and Judicial Affairs 1996: 220-25)

13 Interviews with PC deputies from various parts of China.

14 Among the 573 cadres recommended for approval by the provincial Party committee in 1988, 94 or 16.4 percent of them were rejected by the PPCs (Won and Fu 1991: 51).

15 PPC committees are numbered between two to eight, with five and six the medium. (Quanguo renmin daibiao dahui zhuanmen weiyuanhui gongzuo shouce 1992: appendix).

\section{REFERENCES}

Canon, David T. 1989. 'The Institutionalization of Leadership in the U.S. Congress.' Legislative Studies Quarterly 14 (August): 415-43.

Cheng, Joseph Y. S. 1983. 'How to Strengthen the National People's Congress and Implement Constitutionalism.' Chinese Law and Government 16: 88-122.

Chao, Chien-min 1999. 'Dangguo tizhi xia dang yu lifa jigou guanxi de ruogan sikao.' [A Few Reflections on the Relations between the Party and the Legislative Organs under the PartyState System] Zhongguo dalu yanjiu [Mainland China Studies]. Taipei (September): 13-25.

Chao, Chien-min and Chang Chun-hsiang 2000. Zhonghua renmingongheguo lifa yu xianju zhidu [Electoral and Legislative Systems in the PRC] Taipei: Guoli bianyi guan.

Colton, Timothy J. 1996. 'The Constituency Nexus in the Russian and Other Post-Soviet Parliaments.' In Jeffrey W. Hahn (ed.), Democratization in Russia: The Development of Legislative Institutions. Armonk, NY: M. E. Sharpe.

Dick, Anthony 1989. 'The Chinese Legal System: Reforms in the Balance.' The China Quarterly 119 (September): 540-76. 
Du Gan (ed.) 1998. Jinyibu wanshan difang renda zhidu ruogan wenti yanjiu [Several Issues on Furthering Improvement on the LPC Institution]. Sichuan: Renmin chubanshe.

Hamrin, Carol Lee and Suisheng Zhao (eds) 1995. Decision-making in Deng's China: Perspectives from Insiders. Armonk, NY: M. E. Sharpe.

Huntington, Samuel P. 1990. 'Congressional Responses to the Twentieth Century'. In Pietro S. Nivola and David H. Rosenbloom (eds), Classic Readings in American Politics. New York: St Martin's Press.

Lieberthal, Kenneth 1995. Governing China: From Revolution through Reform. New York: W. W. Norton \& Company.

Liu Zheng, Yu Youmin and Cheng Xiangqing (eds) 1991. Renmin daibiao dahui gongzuo quanshu [Handbook on the Work of People's Congress] Beijing: Zhongguo fazhi chubanshe.

Loewenberg, Gerhard, Samuel C. Patterson and Malcolm E. Jewell (eds) 1985. Handbook of Legislative Research. Cambridge, MA.: Harvard University Press.

McCormick, Barret L. and Jonathan Unger (eds) 1996. China after Socialism: In the Footsteps of Eastern Europe or East Asia? New York: M. E. Sharpe.

Nathan, Andrew 1996. 'China's Constitutionalist Option.' Journal of Democracy 7 (4): 43-57

NPC Committee on Internal and Judicial Affairs 1992. Quanguo renmin daibiao dahui zhuanmen weiyuanhui gongzuo shouce [Manual for the Work of NPC Special Committees]. Beijing: Zhongguo minzhu fazhi chubanshe.

NPC Committee on Internal and Judicial Affairs 1996. Renda jiandu gongzuo shouce [Handbook for the Work of PC Oversight]. Beijing: Zhongguo minzhu fazhi chubanshe.

O'Brien, Kevin 1988. 'China's National People's Congress: Reform and Its Limits.' Legislative Studies Quarterly 13 (August): 343-74.

1989. 'Legislative Development and Chinese Political Change.' Studies in Comparative Communism (Spring).

- 1990a. Reform without Liberalization: China's National People's Congress and the Politics of Institutional Change. Cambridge: Cambridge University Press .

— 1990b. 'Is China's National People's Congress a "Conservative Legislature"?' Asian Survey 30 (8): 782-94.

- 1994. 'Chinese People's Congresses and Legislative Embeddedness: Understanding Early Organizational Development.' Comparative Political Studies 27 (1): 80-107.

- 1998. 'Institutionalizing Chinese Legislatures: Trade-offs between Autonomy and Capacity.' Legislative Studies Quarterly 23(1): 91-108.

Polsby, Nelson W. 1968. 'The Institutionalization of the U.S. House of Representatives.' The American Political Science Review 62: 144-68.

PRC National People's Congress, NPCSC communiqué, 1991-98.

Quanguo renda changweihui bangongting yanjiushi (ed.) 1990. Zhonghua renmin gongheguo renmin daibiao dahui wenxian ziliao hubian 1949-1990 [Compilation of Documents on the PRC's NPC]. Beijing: Zhongguo minzhu fazhi chubanshe.

Quanguo renda changweihui bangongting yanjiushi (ed.) 1998. Zhongjie, tansuo, zhanwang [Summarization, Exploration, and Future Prospects]. Beijing: Zhongguo minzhu fazhi chubanshe.

Scalapino, Robert 1993. 'China in the Late Leninist Era.' The China Quarterly 136 (December): 949-71.

Schuttemeyer, Suzanne S. 1994. 'Hierarchy and Efficiency in the Bundestag: The German Answer for Institutionalizing Parliament.' In Gary W. Copeland and Samuel C. Patterson (eds), Parliaments in the Modern World: Changing Institutions. Ann Arbor, MI: University of Michigan Press.

Shepsle, Kenneth A.1988. 'Representation and Governance: The Great Legislative Tradeoff.' Political Science Quarterly 103: 461-84. 
Skilling, Gordon H. 1973. 'Opposition in Communist East Europe'. In Robert A. Dahl (ed.), Regimes and Oppositions. New Haven, CT: Yale University Press.

Solinger, Dorothy 1982. 'The Fifth National People's Congress and the Process of Policy Making: Reform, Readjustment, and the Opposition.' Asian Survey 22 (12): 1238-83.

Squire, Peverill 1992. 'The Theory of Legislative Institutionalization and the California Assembly.' Journal of Politics 54: 1026-54.

Tanner, Murray Scot 1994. 'The Erosion of Communist Party Control over Lawmaking in China.' The China Quarterly 138 (June): 381-403.

- 1995. 'How a Bill Becomes a Law in China: Stages and Processes in Lawmaking.' The China Quarterly 141 (March): 39-64.

Tucker, Robert C. 1967. 'The Deradicalization of Marxist Movements.' The American Political Science Review 61 (2): 343-58.

Weng, Byron 1982. 'Some Key Aspects of the 1982 Draft Constitution of the PRC.' The China Quarterly 91: 492-50.

Won Wenzou and Fu Lunhe 1991. 'Shilun wanshan difang guojia quanli jiguan de juece zhineng.' [Ways to Improve the Decision-making Function of the Local People's Congress]. Faxue (August): 51.

Wu Guoguang 1999. 'Cong paixi jingzheng dao zhidu jingzheng.' [From Factional Competition to Systemic Competition]. In Lin Jialung (ed.), Liangan dangguo tizhi yu minzhu fazhan [The Party-state System across the Strait of Taiwan and Democratic Development]. Taipei: Yuedan Publishing Co.: 327-38.

Yan Huai 1995. 'Organizational Hierarchy and the Cadre Management System.' In Carol Lee Hamrin and Suisheng Zhao (eds), Decision-making in Deng's China: Perspectives from Insiders. New York: M. E. Sharpe: 39-50.

Yang Shengchun 1997. Zhonghua renmin gongheguo guohui zhi bianqian [Evolution of the PRC's Parliament]. Gaoxiung: Huwen tushu chubanshe.

Zhang Yuankun 1997. Difang renda gongzuo gailun [Introduction to the Work of Local People's Congress]. Beijing: Zhongguo minzhu fazhi chubanshe.

Zhang Wei 1996. Renmin daibiao dahui jiandu zhineng yanjiu [AStudy on Oversight Functions of the People's Congresses]. Beijing: Zhongguo fazhi chubanshe.

Zhou Wei 1998. Geguo lifa jiguan weiyuanhui zhidu bijiao yanjiu [A Comparative Study on the System of Legislative Committees]. Dissertation, Wuhan University. 